\title{
Role of Calcium in Neurotensin-Evoked Enhancement in Firing in Mesencephalic Dopamine Neurons
}

\author{
Fannie St-Gelais, ${ }^{1,2}$ Mark Legault, ${ }^{1,3}$ Marie-Josée Bourque, ${ }^{1}$ Pierre-Paul Rompré, ${ }^{2,3}$ and Louis-Eric Trudeau ${ }^{1,2,3}$ \\ ${ }^{1}$ Département de Pharmacologie, ${ }^{2}$ Centre de Recherche en Sciences Neurologiques, and ${ }^{3}$ Centre de Recherche Fernand Seguin, Université de Montréal, \\ Montréal, Québec, Canada H3T IJ4
}

Neurotensin (NT) increases neurotransmission within the mesolimbic dopamine system by enhancing the firing rate of dopaminergic (DAergic) neurons and by acting at the nerve terminal level. The signal transduction pathways involved in these effects have not been characterized, but NT receptors are coupled to the phospholipase $\mathrm{C}$ pathway and $\mathrm{Ca}^{2+}$ mobilization. However, an enhancement of intracellular $\mathrm{Ca}^{2+}$ concentration $\left(\left[\mathrm{Ca}^{2+}\right]_{\mathrm{i}}\right.$ ) evoked by NT in DAergic neurons has yet to be demonstrated. Furthermore, the hypothesis that the excitatory effects of NT in DAergic neurons are $\mathrm{Ca}^{2+}$ dependant is currently untested. In whole-cell recording experiments, DAergic neurons in culture were identified by their selective ability to express a cell-specific green fluorescent protein reporter construct. These experiments confirmed that NT increases firing rate in cultured DAergic neurons. This effect was $\mathrm{Ca}^{2+}$ dependent because it was blocked by intracellular dialysis with BAPTA. Using $\mathrm{Ca}^{2+}$ imaging, we showed that NT caused a rapid increase in $\left[\mathrm{Ca}^{2+}\right]_{\mathrm{i}}$ in $\mathrm{DAergic}^{2}$ neurons. Most of the $\mathrm{Ca}^{2+}$ originated from the extracellular medium. NT-induced excitation and $\mathrm{Ca}^{2+}$ influx were blocked by SR48692, an antagonist of the type 1 NT receptor. Blocking $\mathrm{IP}_{3}$ receptors using heparin prevented the excitatory effect of NT. Moreover, $\mathrm{Zn}^{2+}$ and SKF96365 both blocked the excitatory effect of NT, suggesting that nonselective cationic conductances are involved. Finally, although NT can also induce a rise in $\left[\mathrm{Ca}^{2+}\right]_{\mathrm{i}}$ in astrocytes, we find that NT-evoked excitation of DAergic neurons can occur independently of astrocyte activation.

Key words: neurotensin; dopamine; ventral tegmental area; patch clamp; intracellular calcium; calcium imaging; primary culture

\section{Introduction}

Neurotensin (NT) and its receptors are present in high density in the ventral mesencephalon (Palacios and Kuhar, 1981; Szigethy and Beaudet, 1989; Dana et al., 1991). They are also present on astrocytes (Nouel et al., 1999; Trudeau, 2000). Although the physiological role of this peptide is unclear, it may play a role in regulating dopaminergic (DAergic) neuronal pathways involved in reward (Rompre et al., 1992) and may be perturbed in schizophrenia (Govoni et al., 1980; Kinkead et al., 2000).

NT generally enhances dopamine release (Kalivas et al., 1983; Cador et al., 1989; Stowe and Nemeroff, 1991). It acts both at the nerve terminal (Hetier et al., 1988; Faggin et al., 1990; Heaulme et al., 1997; Legault et al., 2002) and at the somatodendritic level in which it enhances firing rate (Pinnock, 1985; Seutin et al., 1989; Jiang et al., 1994; Nalivaiko et al., 1998; Werkman et al., 2000). The effects of NT on DAergic neurons are thought to be primarily

\footnotetext{
Received July 15, 2003; revised Jan. 16, 2004; accepted Jan. 17, 2004

This work was funded by grants from the National Science and Engineering Research Council of Canada (NSERC) and from the National Alliance for Research on Schizophrenia and Depression. M.L. was supported by a postdoctora fellowship from NSERC. The plasmid (hDAT-6250EGFP) was kindly provided by Dr. Michael Bannon (Faculty of Medicine, Wayne State University, Detroit, MI). The NT receptor antagonists were kindly provided by Dr. Danièle Gully (Sanofi-Synthélabo, Paris, France). We thank Marie-Josée Bourque and Isabel Jutras for preparation of cell cultures.

Correspondence should be addressed to Dr. Louis-Eric Trudeau, Département de Pharmacologie, Université de Montréal, 2900 Boulevard Édouard-Montpetit, Montréal, Québec, Canada, H3T 1J4. E-mail: louis-eric.trudeau@umontreal.ca.

D01:10.1523/JNEUROSCI.5376-03.2004

Copyright $\odot 2004$ Society for Neuroscience $\quad 0270-6474 / 04 / 242566-09 \$ 15.00 / 0$
}

mediated by NTS1, a G-protein-coupled receptor that is highly expressed in DAergic neurons (Mazella et al., 1996). In the mesencephalic brain slice preparation, the enhancement in firing rate caused by NT is blocked by SR142948A, a wide-spectrum NT receptor antagonist that blocks both NTS1 and NTS2, the latter being the second major brain NT receptor (Nalivaiko et al., 1998).

The depolarizing effect of NT on DAergic neurons has been suggested to require activation of nonspecific cationic conductances, perhaps accompanied by a reduction in a $\mathrm{K}^{+}$conductance (Mercuri et al., 1993; Jiang et al., 1994; Farkas et al., 1996). The inward current induced by NT in DAergic neurons is blocked by the selective NTS1 antagonist SR48692 (Wu et al., 1995; Farkas et al., 1996). How NTS1 modulates such ionic currents is unknown. However, the best characterized signal transduction pathway for this receptor implicates phospholipase C (PLC) (Tanaka et al., 1990; Hermans et al., 1992; Chabry et al., 1994; Wang and Wu, 1996; Martin et al., 1999; Grisshammer and Hermans, 2001). A link between PLC-generated second messengers and the depolarizing effect of NT remains to be established. A preliminary report has proposed that $\mathrm{Ca}^{2+}$ mobilization and $\mathrm{IP}_{3}$ receptor activation are necessary for the enhancement by NT of a nonselective cationic current (Wu et al., 1995); however, NT reportedly still excites DAergic neurons in low external $\mathrm{Ca}^{2+}$ (Seutin et al., 1989). Finally, it has been reported previously that NT causes a rise in intracellular $\mathrm{Ca}^{2+}$ in cultured cortical cells (Sato et al., 1991), in cultured mesencephalic astrocytes 
(Trudeau, 2000), and in neurons acutely dissociated from the raphe and periaqueductal gray nuclei (Li et al., 2001a,b). However, an NT-evoked increase in intracellular $\mathrm{Ca}^{2+}$ in DAergic neurons has not yet been described.

In the present experiments, we tested the hypothesis of a relationship between NT-evoked enhancement in firing and NTevoked increases in intracellular $\mathrm{Ca}^{2+}$. Our results suggest that an increase in intracellular $\mathrm{Ca}^{2+}$ is necessary for NT-induced firing rate increase and that the $\mathrm{IP}_{3}$ pathway and nonselective cationic channels are involved.

\section{Materials and Methods}

Cell culture. Primary cultures of ventral mesencephalon were prepared from rats aged from 1 to $3 \mathrm{~d}$ according to previously described protocols (Bourque and Trudeau, 2000; Michel and Trudeau, 2000; Congar et al., 2002) derived from Cardozo (1993) and Sulzer et al. (1998). Briefly, animals were cryoanesthetized, brains were rapidly removed, and a coronal section $(\sim 1 \mathrm{~mm}$ thick) was prepared at the level of the midbrain flexure. Bilateral tissue blocks containing substantia nigra and a medial block containing the ventral tegmental area (VTA) were then dissected. The blocks were incubated in papain for $30 \mathrm{~min}$ and dissociated. After trituration in a solution containing $10 \%$ fetal bovine serum, cells were centrifuged. The supernatant was removed, and the cells were resuspended and plated on $15 \mathrm{~mm}$ coverslips that had been seeded previously with mesencephalic astrocytes.

Two astrocyte culture protocols were used. In most experiments, mesencephalic astrocytes were grown in flasks for $48 \mathrm{hr}$ and then washed with cold medium to eliminate neurons and many astrocytes, conserving only highly adherent astrocytes. Such purified astrocytes were then transferred to coverslips before plating neurons. A subset of experiments was also performed on primary astrocytes, which were directly plated on coverslips, without selection and growth in flasks. We reported previously that a proportion of primary mesencephalic astrocytes respond to NT by a rise in $\left[\mathrm{Ca}^{2+}\right]_{\mathrm{i}}$ (Trudeau, 2000). In preliminary experiments, we discovered that purified astrocytes grown in flasks fail to respond to NT. As indicated, experiments were performed to determine whether the effect of NT on DAergic neurons was the same under conditions in which astrocytes respond or not to NT.

Cultures were maintained in Neurobasal A/BMEM (2:1) supplemented with penicillin-streptomycin, glutaMAX-1, B27 serum extender (Invitrogen, Burlington, Ontario, Canada), and 10\% fetal calf serum (HyClone, Logan, UT). Cultures matured for at least $9 \mathrm{~d}$ before experimentation.

Immunolabeling and transfection. After each experiment, a small injection of fluorescent microspheres (FluoSpheres; Molecular Probes, Eugene, OR) was made into the glial layer near the tested cells to locate the neurons after immunolabeling. Identification of DAergic neurons was made using an antibody directed against tyrosine hydroxylase (TH). Briefly, cells were fixed in $4 \%$ paraformaldehyde and then incubated with a mouse monoclonal TH antibody (Sigma, St. Louis, MO). Fluorescent secondary antibodies (Alexa-488 or Alexa-546; Molecular Probes) were used to visualize the primary antibody on an epifluorescence miscroscope (Eclipse TE-200; Nikon, Montreal, Quebec, Canada).

A selective transfection strategy was developed to identify DAergic neurons for patch-clamp recordings. This was required because DAergic neurons represent only $15-25 \%$ of the cells in postnatal mesencephalic cultures. Cells were transfected using the $\mathrm{Ca}^{2+}$ phosphate coprecipitation technique with a plasmid containing the coding sequence of enhanced green fluorescent protein (EGFP) under the control the dopamine transporter promoter (hDAT-6250EGFP plasmid kindly provided by Dr. Michael Bannon, Faculty of Medicine, Wayne State University, Detroit, MI). Although this permitted preferential transfection of DAergic neurons, TH immunolabeling was nonetheless always performed to confirm the DAergic phenotype of the recorded neurons. Approximately $85 \%$ of neurons showing strong GFP expression after transfection were confirmed to be DAergic (see Fig. $1 \mathrm{~A}$ ). This technique thus allowed us to greatly improve the success of patch-clamp recording experiments.

Electrophysiology. Electrophysiological experiments were performed in a recording perfusion chamber mounted on an inverted fluorescence microscope. Neurons were perfused using a gravity flow system (2.5 $\mathrm{ml} / \mathrm{min}$ ) with standard saline at room temperature. The standard saline contained the following (in mM): $140 \mathrm{NaCl}, 5 \mathrm{KCl}, 2 \mathrm{MgCl}_{2}, 2 \mathrm{CaCl}_{2}, 10$ HEPES, 6 sucrose, and 10 glucose, pH 7.35 (300 mOsm). Action potential firing was measured using the ruptured or perforated (amphotericin B, $150-200 \mathrm{mg} / \mathrm{ml}$ ) patch-clamp technique. No differences were noted between recordings obtained with the two techniques. All results were thus pooled. Patch pipettes were made from borosilicate capillary tubes (resistance 3-6 M $\Omega$ ) filled with a potassium methylsulfate solution containing the following (in $\mathrm{mm}$ ): 120 potassium methylsulfate, $20 \mathrm{KCl}, 5$ $\mathrm{NaCl}$, 0.1 EGTA, 2 MgATP, 0.5 GTP (Tris salt), 10 HEPES, and 10 phosphocreatine, $\mathrm{pH} 7.35$ (300 mOsm). To evaluate the effect of NT(8-13) in the presence of BAPTA, the pipette solution contained the following (in $\mathrm{mm}$ ): 100 potassium methylsulfate, $20 \mathrm{KCl}, 5 \mathrm{NaCl}, 0.1 \mathrm{EGTA}, 2 \mathrm{MgATP}$,

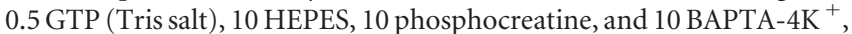
pH 7.35 (300 mOsm). The electrophysiological signal was amplified and filtered at $1 \mathrm{kHz}$ using a PC-505 patch-clamp amplifier (Warner Instruments, Hamden, CT). This signal was digitized at $5 \mathrm{kHz}$ using a Digidata 1200 analog-to-digital converter and Clampex 8.0 software (Axon Instruments, Foster City, CA). Neurons were recorded under currentclamp mode. Basal firing rate varied significantly between cells and between cultures, which explains the differences of this parameter between experiments (for details, see figure legends). This variability could be attributable to a number of factors, such as the density of plated neurons and the extent of connectivity between neurons, both of which change during maturation of the cultures. Action potential firing rate was analyzed using Mini Analysis 5.2 software (Synaptosoft, Leona, NJ). Firing rates were analyzed as the number of action potentials per $15 \mathrm{sec}$ bin. Data are expressed in delta, which is the difference between numbers of action potentials per bin compared with the average number of action potentials during the control bins. Data in the text and figures are expressed as mean \pm SEM.

Fluorescence calcium imaging. Fluorescence imaging experiments were performed using an inverted Olympus Optical (Tokyo, Japan) IX50 microscope and a Hamamatsu (Bridgewater, NJ) ORCA-100 digital camera. The camera was attached to a multi-purpose optical workbench from Prairie Technologies (Middleton, WI). Images were captured using Stack Function software by Prairie Technologies. Images were captured at a rate of $0.5 \mathrm{~Hz}$. Except otherwise indicated, for $\mathrm{Ca}^{2+}$ imaging experiments, neurons were loaded with Calcium Green-1 AM (5 $\mu \mathrm{M})$ (Molecular Probes) at room temperature, for at least $30 \mathrm{~min}$. In a series of experiments, the contribution of $\mathrm{Ca}^{2+}$ influx was determined by testing some cells in $\mathrm{Ca}^{2+}$-free saline containing the following (in $\mathrm{mM}$ ): 140 $\mathrm{NaCl}, 5 \mathrm{KCl}, 4 \mathrm{MgCl}_{2}, 6$ sucrose, 10 glucose, 10 HEPES, and 1 EGTA. This solution was perfused for 3 min before the application of NT(8-13). At the end of each experiment, saline containing $40 \mathrm{~mm}$ potassium was perfused for $30 \mathrm{sec}$ to determine whether the cell was healthy and had the ability to show a rise in $\left[\mathrm{Ca}^{2+}\right]_{i}$.

For data analysis, baseline was taken as the mean fluorescence intensity of a cell over the $10 \mathrm{sec}$ (five images) immediately preceding NT(8-13) application. Neurotensin-evoked $\mathrm{Ca}^{2+}$ fluorescence change for each individual cell was expressed as the change in fluorescence intensity relative to the baseline signal of each individual cell. Neurons were determined to have responded to NT(8-13) with changes in $\left[\mathrm{Ca}^{2+}\right]_{\mathrm{i}}$ if they met the following criteria: a cell had to have a change in its fluorescent ratio of at least $5 \%$; that change had to be sustained for at least $20 \mathrm{sec}$, and, finally, the neurons had to respond to high potassium saline.

Statistical analysis. NT(8-13)-evoked changes in cell firing involved simple two-group comparisons and were thus analyzed by Student's paired $t$ tests. To quantify maximal effects, the mean value of control and wash periods was compared with the mean of the two bins showing the highest change in firing frequency in the $2 \mathrm{~min}$ after the beginning of NT(8-13) application. Analyses were performed in this way because the effect of NT(8-13) on firing rate occurred after variable delays.

Neurotensin-evoked changes in Calcium Green-1 fluorescence were assessed by two-way ANOVAs and Tukey's post hoc tests. Statistical analyses were performed on data from baseline to the first $90 \mathrm{sec}$ after the initiation of NT perfusion. Analyses were limited to this time range be- 
cause the effects of NT(8-13) and other treatments were clearly evident within this period.

Drugs. Tetrodotoxin (TTX) was purchased from Alomone Labs (Jerusalem, Israel). Unless otherwise mentioned, all other drugs and products were purchased from Sigma. In all experiments, the 8-13 active fragment of NT [NT(8-13); thereafter NT] was used as an NT receptor agonist. Neurotensin receptor antagonists were generously provided by Dr. Danièle Gully (Sanofi-Synthélabo, Paris, France).

\section{Results}

\section{NT-evoked enhancement in firing in DAergic neurons}

In patch-clamp recording experiments, DAergic neurons were recognized by their selective ability to express GFP after transfection with a plasmid allowing expression of GFP under the control of the dopamine transporter (DAT) promoter (Fig. 1A). Although only a minority of neurons were transfected (1-5\% transfection efficiency), the majority of transfected neurons showing strong expression of GFP were confirmed to be DAergic by postrecording immunolabeling for TH (Fig. $1 A$ ) (see Materials and Methods). NT is recognized to increase the excitability of DAergic neurons. As expected, current-clamp recordings from identified DAergic neurons showed that NT (100 nM) induced an increase in firing rate (Fig. $1 B, C$ ). The basal firing rate of dopamine neurons was, on average, $1.05 \pm 0.05 \mathrm{~Hz}(n=10)$. Because basal firing rate was low in some cells, results were expressed as a relative change from baseline firing rate. Typically, the excitatory effect of NT was delayed; in most cells, the increase in firing rate occurred after a delay of $30-45 \mathrm{sec}$. Although the average effect of NT was excitatory, some response variability was observed: of 10 DAergic neurons recorded, 7 showed an increase in firing rate in response to NT, 2 showed no change, and 1 neuron showed a decrease in firing rate. In the seven neurons that showed an increase in firing rate, NT-evoked excitation was accompanied by a small depolarization of the resting membrane potential $(2.7 \pm$ $0.2 \mathrm{mV}$ ) (data not shown), compatible with previous reports of NT-evoked inward currents and depolarization in DAergic neurons (Mercuri et al., 1993).

The role of $\mathrm{Ca}^{2+}$ in NT-evoked increase in firing was evaluated using BAPTA, a $\mathrm{Ca}^{2+}$ chelator. NT failed to enhance firing rate when BAPTA $(10 \mathrm{mM})$ was included in the patch pipette $(n=$ 10) (Fig. 1C). These results show that the mechanism by which NT increases firing rate in DAergic neurons depends on intracellular $\mathrm{Ca}^{2+}$.

\section{Effects of NT on intracellular calcium}

The $\mathrm{Ca}^{2+}$ dependency of NT-induced increase in firing rate suggests that NT increases intracellular $\mathrm{Ca}^{2+}$ concentration $\left(\left[\mathrm{Ca}^{2+}\right]_{\mathrm{i}}\right)$ in DAergic neurons. It has been shown previously that NT can increase $\left[\mathrm{Ca}^{2+}\right]_{\mathrm{i}}$ in other cell types, such as in astrocytes (Trudeau, 2000), cortical cells (Sato et al., 1991), and amacrine cells of the retina (Borges et al., 1996). However, such an effect has never been demonstrated in DAergic neurons. To investigate the hypothesis of NT-evoked elevation in $\mathrm{Ca}^{2+}$ in DAergic neurons, variations in $\left[\mathrm{Ca}^{2+}\right]_{i}$ were monitored by fluorescence imaging using Calcium Green-1 AM. We found that NT rapidly and robustly increased $\left[\mathrm{Ca}^{2+}\right]_{\mathrm{i}}$ in cultured DAergic neurons (Fig. $2 A)$. The magnitude of the increase in $\left[\mathrm{Ca}^{2+}\right]_{i}$ produced by NT was dose dependent, with a plateau being reached after $1 \mathrm{~nm}$ (Fig. $2 B$ ) (one-way ANOVA; $F_{(4,43)}=3.68 ; p<0.05$ ). Although average increases in $\left[\mathrm{Ca}^{2+}\right]_{\mathrm{i}}$ were slightly smaller at 10 and $100 \mathrm{nM}$, there was no statistically significant difference between the response obtained at $1 \mathrm{~nm}$ and the responses obtained at 10 or 100 $\mathrm{nM}(p>0.05)$. The rise in $\left[\mathrm{Ca}^{2+}\right]_{\mathrm{i}}$ was detectable within $6 \mathrm{sec}$ after the beginning of drug application at 10 and $100 \mathrm{nM}$, whereas
A)
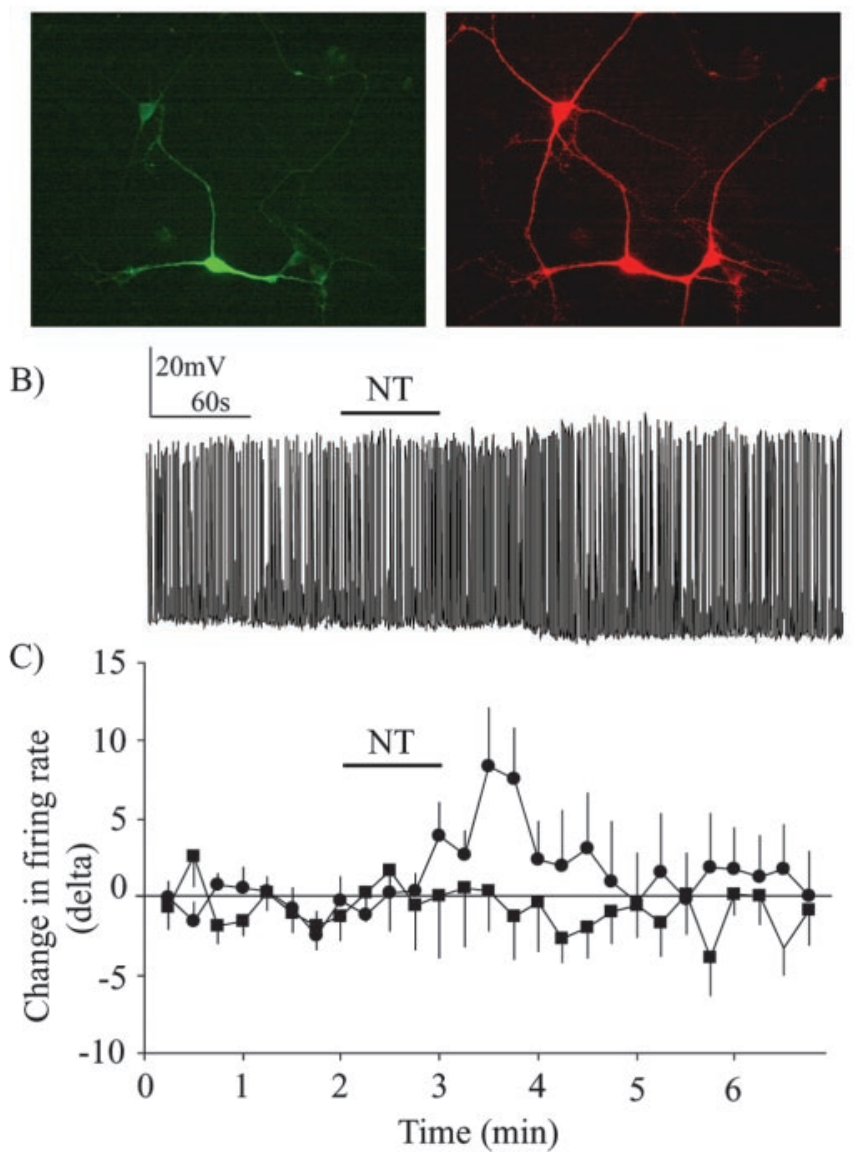

Figure 1. Neurotensin induces $\mathrm{Ca}^{2+}$-dependent increase in firing rate in DAergic neurons. $A$, DAergic neurons were identified before patch-clamp recording using a selective transfection strategy allowing the expression of GFP under the control of the dopamine transporter promoter (green neuron; left image). The phenotype of recorded neurons was always confirmed after patch-clamp recording or $\mathrm{Ca}^{2+}$ imaging by detecting $\mathrm{TH}$ immunoreactivity (red signal; right image). Note that the field contained three DAergic neurons, but that only one was transfected with GFP. Scale bar, $15 \mu \mathrm{m}$. B, Whole-cell current-clamp recording of spontaneous action potentials in a DAergic neuron. Perfusion of $100 \mathrm{~nm}$ NT for 1 min (black bar) caused a delayed increase in firing rate. Basal firing rate was, on average, $1.05 \pm 0.05 \mathrm{~Hz}$ in control condition and $1.6 \pm 0.2 \mathrm{~Hz}$ in the presence of neurotensin. C, Summary data showing the change in action potential firing rate caused by bath-applied NT in DAergic neurons under control conditions (black circles) or when the patch pipette contained BAPTA (black squares). The change in firing rate over time is expressed as a difference score (delta) representing the variation in average firing rate within $15 \mathrm{sec}$ bins compared with the average firing rate within the eight initial bins acquired before peptide application. Basal firing rate was, on average, $1.5 \pm 0.1 \mathrm{~Hz}$ in the presence of BAPTA. For statistical comparisons, the average number of action potentials during the control period was compared with the average number of action potentials during the minute after the application of NT (in which the maximal effect was detected in experiments without BAPTA). There was a significant increase in firing in control experiments $(t$ test; $t=4.21 ; p<0.05)$ but not in experiments in which neurons were loaded with BAPTA $(t$ test $; t=0.20 ; p>0.05)$.

at 0.1 and $1 \mathrm{~nm}, 10-12 \mathrm{sec}$ were required (data not shown). At concentrations from 0.1 to $100 \mathrm{nM}$, a significant NT-evoked increase in $\left[\mathrm{Ca}^{2+}\right]_{\mathrm{i}}$ was detectable in $90 \%$ of neurons tested (45 of 50 ), whereas only $23 \%$ of neurons responded to $0.01 \mathrm{~nm} \mathrm{NT}$ ( 3 of 13). To minimize response delays, all additional experiments were performed with $100 \mathrm{~nm}$ NT.

To determine whether NT-evoked intracellular $\mathrm{Ca}^{2+}$ elevation was dependent on NT-evoked enhanced in firing, imaging experiments were performed in the presence of TTX $(0.5 \mu \mathrm{M})$, a blocker of voltage-gated sodium channels that abolishes the 

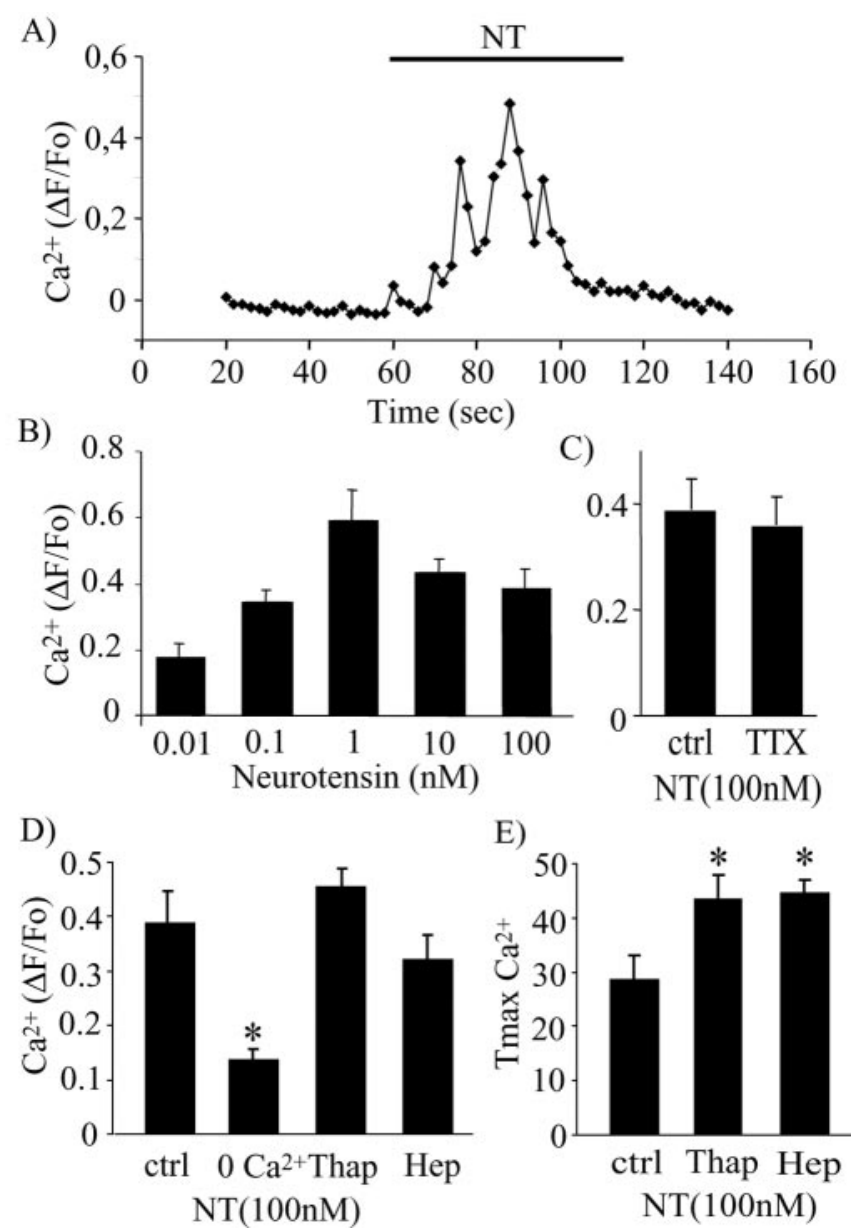

Figure 2. Neurotensin induces calcium influx in DAergic neurons. A, Typical time course of the rise in $\left[\mathrm{Ca}^{2+}\right]_{\mathrm{i}}$ in a DAergic neuron during a 1 min exposure to NT (100 nM). Intracellular $\mathrm{Ca}^{2+}$ concentration was estimated using Calcium Green-1 AM. Data are represented as the mean fluorescence ratio as a function of time $\left(\Delta F / F_{0}\right)$. Images were acquired at a rate of $0.5 \mathrm{~Hz}$. $B$, Dose-response effect of NT on $\left[\mathrm{Ca}^{2+}\right]_{i}$ for NT concentrations ranging from 0.01 to $100 \mathrm{~nm}$ $(0.01 \mathrm{~nm}, n=3 ; 0.1 \mathrm{~nm}, n=12 ; 1 \mathrm{~nm}, n=11 ; 10 \mathrm{~nm}, n=9 ; 100 \mathrm{~nm}, n=13)$. Each bar represents the mean \pm SEM value. $C$, The effect of NT on $\left[\mathrm{Ca}^{2+}\right]_{i}$ persists in the presence of TTX. D, NT-evoked intracellular $\mathrm{Ca}^{2+}$ elevation in DAergic neurons is mostly blocked in the absence of extracellular $\mathrm{Ca}^{2+}\left(0 \mathrm{Ca}^{2+}\right)$ but is maintained after treatment with thapsigargin (Thap) to deplete intracellular $\mathrm{Ca}^{2+}$ stores or after blockade of $\mathrm{IP}_{3}$ receptors with heparin (Hep). $E$, Thapsigargin and heparin cause a delay in the time-to-peak $\left(T_{\max }\right)$ of NT-evoked intracellular $\mathrm{Ca}^{2+}$ elevation. Ctrl, Control.

propagation of action potentials in most neurons, including DAergic neurons (data not shown) (Grace and Onn, 1989; Hausser et al., 1995). NT-evoked elevation in $\left[\mathrm{Ca}^{2+}\right]_{\mathrm{i}}$ was still detectable and not significantly decreased after $3 \mathrm{~min}$ in the presence of TTX ( $n=13$ for control; $n=11$ for TTX) ( $t$ test; $t=0.36$; $p>0.05$ ) (Fig. 2C). The $\mathrm{Ca}^{2+}$ elevation evoked by NT was therefore not activity dependent.

$\mathrm{Ca}^{2+}$-free saline was used to evaluate the relative contribution of intracellular and extracellular $\mathrm{Ca}^{2+}$ sources to the elevation of $\left[\mathrm{Ca}^{2+}\right]_{\mathrm{i}}$ induced by NT. We observed that, although NT still caused a small increase in $\left[\mathrm{Ca}^{2+}\right]_{\mathrm{i}}$ when applied after 3 min perfusion with $\mathrm{Ca}^{2+}$-free saline, the major part of the response was blocked ( $n=13$ for control; $n=15$ for $\mathrm{Ca}^{2+}$-free) $(t$ test; $t=$ 4.37; $p<0.05$ ) (Fig. $2 D$ ). This finding shows that, although both extracellular and intracellular $\mathrm{Ca}^{2+}$ pools can contribute, most of the $\mathrm{Ca}^{2+}$ elevation caused by NT resulted from influx from the extracellular medium. Compatible with a minor involvement of intracellular $\mathrm{Ca}^{2+}$ stores, thapsigargin, a $\mathrm{Ca}^{2+}$ ATPase blocker (1 $\mu \mathrm{M})$ that leads to the depletion of intracellular $\mathrm{Ca}^{2+}$ stores, did not cause a significant decrease in the magnitude of NT-evoked increases in $\left[\mathrm{Ca}^{2+}\right]_{\mathrm{i}}$ in DAergic neurons $(n=17)(t$ test; $t=0.72$; $p>0.05$ ) (Fig. $2 D$ ). The same result was obtained by using heparin, an $\mathrm{IP}_{3}$ receptor antagonist. Heparin $(1 \mathrm{mg} / \mathrm{ml})$ was introduced in individual neurons through whole-cell dialysis during patch-clamp recording. In these experiments, Calcium Green-1 was simultaneously introduced in the recorded neuron as a membrane-impermeant dextran conjugate. The ability of NT to cause an elevation of $\left[\mathrm{Ca}^{2+}\right]_{i}$ was unimpaired in heparin-loaded neurons $(n=5)$ ( $t$ test; $t=0.69 ; p>0.05)$ (Fig. $2 D)$. However, both heparin and thapsigargin caused a significant delay of the onset of NT-evoked $\mathrm{Ca}^{2+}$ elevation (Fig. $2 \mathrm{E}$ ): the time required to reach maximal response amplitude (Tmax) increased from $28 \pm 5 \mathrm{sec}$ in control conditions to $43 \pm 5 \mathrm{sec}$ in the presence of thapsigargin ( $t$ test; $t=2.20 ; p<0.05$ ) and to $44 \pm 3 \mathrm{sec}$ in the presence of heparin ( $t$ test; $t=2.07 ; p<0.05$ ). These results confirm the predominant, although not exclusive, role of extracellular $\mathrm{Ca}^{2+}$ influx in mediating NT-evoked $\left[\mathrm{Ca}^{2+}\right]_{\mathrm{i}}$ elevation in DAergic neurons.

\section{The effect of NT is mediated by NTS1}

We next wanted to determine which subtype of NT receptor mediates the excitatory effect of NT on DAergic neurons. Because NTS1 is expressed at high level in DAergic neurons, we hypothesized that most of the effects of NT observed in our experiments should be mediated by this receptor. Compatible with this hypothesis, SR48692 (1 $\mu \mathrm{M})$, an antagonist that preferentially blocks NTS1, abrogated the enhancement in firing rate caused by $100 \mathrm{~nm}$ NT in DAergic neurons $(n=8$; $t$ test; $t=3.25 ; p>0.05)$ (Fig. 3A). This antagonist also blocked the increase in $\left[\mathrm{Ca}^{2+}\right]_{i}$ induced by NT in most neurons, indicating that most of the $\left[\mathrm{Ca}^{2+}\right]_{\mathrm{i}}$ elevation is mediated by NTS1 (Fig. $3 \mathrm{~B}$ ). Although all of the 15 neurons tested showed an increase $\left[\mathrm{Ca}^{2+}\right]_{\mathrm{i}}$ in response to NT under control conditions, only 4 of 13 showed an increase above criterion level (see Materials and Methods) in the presence of SR48692 (Fig. 3B). SR142948A (100 nM), a nonselective NTS1 and NTS2 antagonist, also abolished the effect of NT on $\left[\mathrm{Ca}^{2+}\right]_{\mathrm{i}}$ increase ( 2 responsive neurons out of 17 tested) (Fig. $3 B$ ). The average increase in $\left[\mathrm{Ca}^{2+}\right]_{\mathrm{i}}$ across all neurons tested in the presence of SR48692 or SR142948A was also significantly smaller than in control neurons $\left(0.02 \pm 0.03\right.$ and $0.010 \pm 0.005 \Delta F / F_{\mathrm{o}}$, respectively, compared with $0.24 \pm 0.04$ for the control group; one-way ANOVA, $F_{(2,42)}=19.52, p<0.05$; pairwise comparisons; Tukey's test, $p<0.05)$. There was no significant difference between the rise in $\left[\mathrm{Ca}^{2+}\right]_{\mathrm{i}}$ induced by NT in the presence of the two antagonists (Tukey's test; $p<0.05$ ).

\section{Neurotensin-evoked excitation of DAergic neurons occurs independently of astrocyte activation}

We reported previously that NT can induce a rise in $\left[\mathrm{Ca}^{2+}\right]_{\mathrm{i}}$ in astrocytes (Trudeau, 2000). Because $\left[\mathrm{Ca}^{2+}\right]_{\mathrm{i}}$ elevation can induce the release of excitatory messengers from astrocytes (Araque et al., 1998), we evaluated whether NT-evoked excitation of DAergic neurons requires astrocyte activation. We discovered in preliminary experiments that purified astrocytes grown in flasks only rarely respond to NT by an increase in $\left[\mathrm{Ca}^{2+}\right]_{\mathrm{i}}$ : only $4 \pm 2 \%$ of astrocytes show a detectable response (Fig. $4 A$ ). However, in primary cultures of mesencephalic astrocytes, a response to NT can be detected in $39 \pm 4 \%$ of astrocytes (Fig. $4 A$ ). The response of neurons to NT under conditions in which astrocytes are responsive or not to NT was thus compared. We found that NT increased the firing rate of DAergic neurons under both condi- 

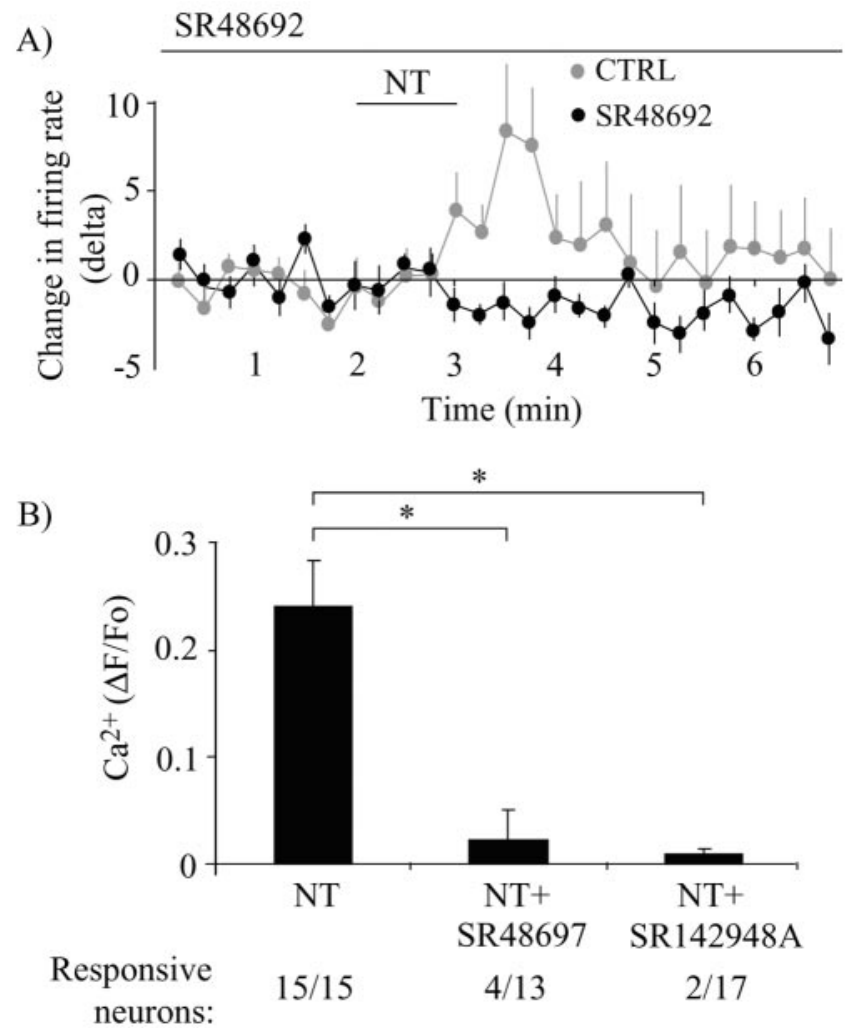

Figure 3. The effect of NT on firing rate is mediated by the NTS1 receptor. A, SR48692 $(1 \mu \mathrm{M})$, an NTS1 receptor antagonist, blocked the effect of NT (100 nM) on the firing rate of DAergic neurons (black circles). The response of the control group (CTRL) (from Fig. 1C) is shown for comparison (gray circles). Basal firing rate in the presence of SR48692 was, on average, $0.6 \pm$ $0.1 \mathrm{~Hz}$. B, The elevation in $\left[\mathrm{Ca}^{2+}\right]_{i}$ induced by NT was also blocked by SR48692 and by SR142948A, a broader-spectrum NT receptor antagonist. The number of neurons responding to NT as a function of the total number of neurons tested is indicated below each column (Responsive neurons).

tions (Fig. 4B). This finding demonstrates that activation of astrocytes is not required for excitation of DAergic neurons by NT. However, a quantitative comparison of firing rate increases revealed that, when neurons are plated on responding astrocytes, there is a significantly greater increase in the firing rate in response to NT (two-way ANOVA; $F_{(1,240)}=5.108 ; p<0.05$ ).

\section{Intracellular pathway mediating the excitatory effect of NT}

It is known that NTS1 is a $\mathrm{G}_{\mathrm{q}}$-coupled receptor and that it activates PLC (Yamada et al., 1994). This activation generates $\mathrm{IP}_{3}$ and DAG, which, respectively, lead to $\mathrm{Ca}^{2+}$ mobilization from intracellular pools and to the formation of PKC. Selective antagonists were used to evaluate the implication of $\mathrm{IP}_{3}$ and $\mathrm{PKC}$ in the excitatory effects of NT. Preincubation with the PKC inhibitor bisindolylmaleimide $(1 \mu \mathrm{M})$ did not prevent NT from significantly increasing the firing rate of DAergic neurons $(n=8 ; t$ test; $t=2.47 ; p<0.05)$ (Fig. 5A). However, intra-pipette inclusion of heparin $(1 \mathrm{mg} / \mathrm{ml})$, an $\mathrm{IP}_{3}$ receptor antagonist, completely blocked the excitatory effect of NT $(n=6 ; t$ test; $t=1.55 ; p>$ 0.05 ) (Fig. 5B). We conclude that some step implicating the $\mathrm{IP}_{3}$ receptor is required for NTS1 to cause excitation of DAergic neurons.

Although a number of steps may be involved between $\mathrm{IP}_{3}$ receptor activation and excitability changes, it has been shown previously that NT can cause the opening of cationic channels in DAergic neurons. Considering recent findings suggesting direct
A)

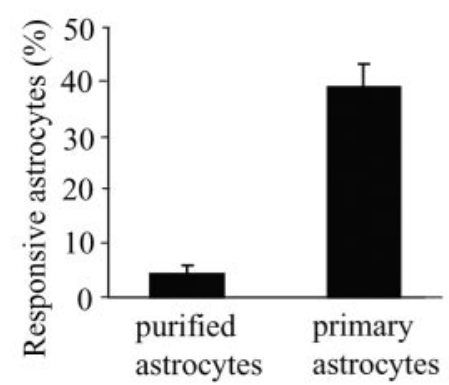

B)

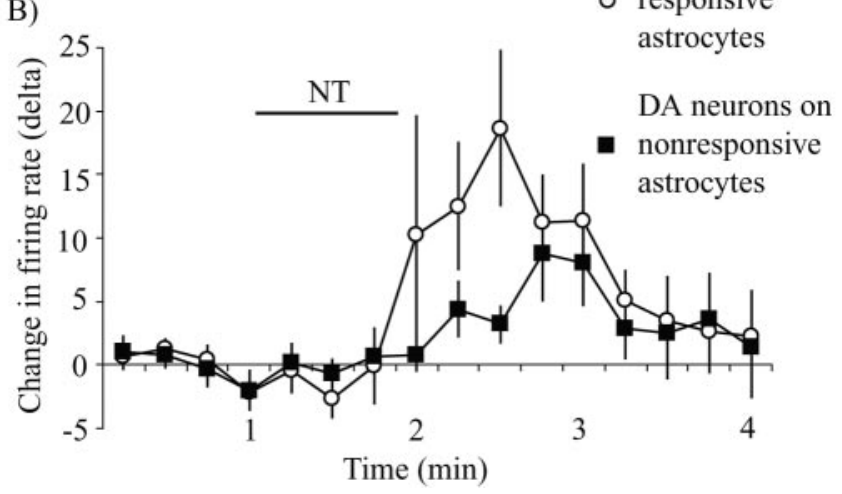

Figure 4. Neurotensin-evoked excitation of DAergic neurons occurs independently of astrocyte activation. $A$, Graph representing the proportion of astrocytes that demonstrate an increase in $\left[\mathrm{Ca}^{2+}\right]_{\mathrm{i}}$ in response to NT $(100 \mathrm{~nm})$. Whereas a response was obtained in a significant proportion of primary mesencephalic astrocytes in culture, this was almost never observed in purified astrocyte cultures initially grown in flasks. $B$, Comparison of the NT-evoked enhancement in firing rate in DAergic neurons when grown together with responsive (open circles) $(n=$ 7) or nonresponsive (dark squares) astrocytes $(n=10)$. The time course of the change in firing rate over time is expressed as a difference score (delta) representing the variation in average firing rate within $15 \mathrm{sec}$ bins compared with the average firing rate within the eight initial bins acquired before peptide application. Basal firing rate was, on average, $0.40 \pm 0.05 \mathrm{~Hz}$ in neurons grown on responsive astrocytes and $1.05 \pm 0.05$ in neurons grown on nonresponsive astrocytes. NT was used at $100 \mathrm{~nm}$.

links between the $\mathrm{IP}_{3}$ receptor and cationic channels of the TRP (transient receptor potential) family (Boulay et al., 1999; Kiselyov et al., 1999), we evaluated the implication of such channels using $\mathrm{Zn}^{2+}$, an inorganic cation shown recently to block a subset of TRP channels in neurons (Kaneko et al., 2002). Compatible with the implication of cationic channels, $\mathrm{ZnCl}(10 \mu \mathrm{M})$ completely antagonized the increase in cell firing induced by NT, actually revealing a small decrease in firing $(n=6 ; t$ test; $t=2.77 ; p<$ 0.05) (Fig. 5C). Moreover, SKF96365 (1 $\mu \mathrm{M})$, another broadly used blocker of cationic channels (Merritt et al., 1990), completely blocked the excitatory effect of NT $(n=5 ; t$ test; $t=1.09$; $p<0.05$ ) (Fig. 5D).

\section{Discussion}

Our results provide new insight into the mechanism mediating the well known excitatory effect of NT on DAergic neurons. We demonstrate that this effect is $\mathrm{Ca}^{2+}$ dependent and implicates $\mathrm{IP}_{3}$ receptors and SKF96365-sensitive channels. Our selective transfection strategy coupled with immunohistochemical identification of DAergic neurons represents an advantage over previous studies of NT action in the VTA in which neurons were presumed to be DAergic solely on the basis of morphology and electrophysiological characteristics (Seutin et al., 1989; Jiang et al., 1994; Farkas et al., 1996; Werkman et al., 2000). 


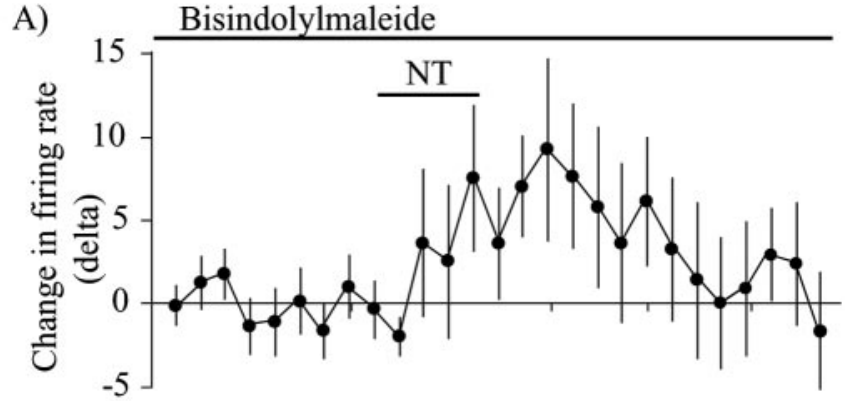

B)

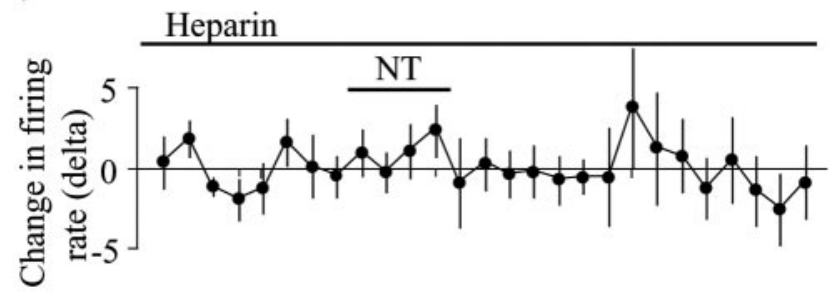

C)

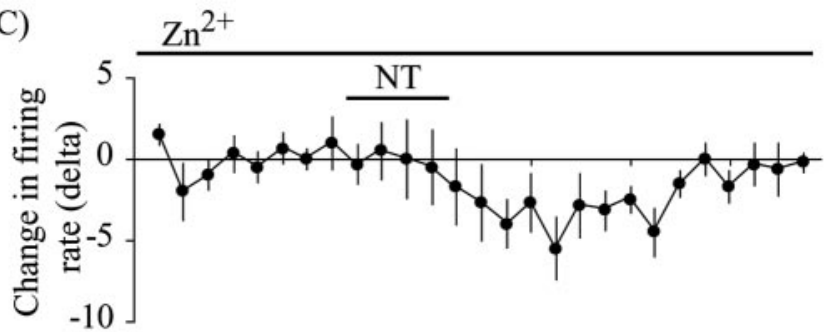

D)

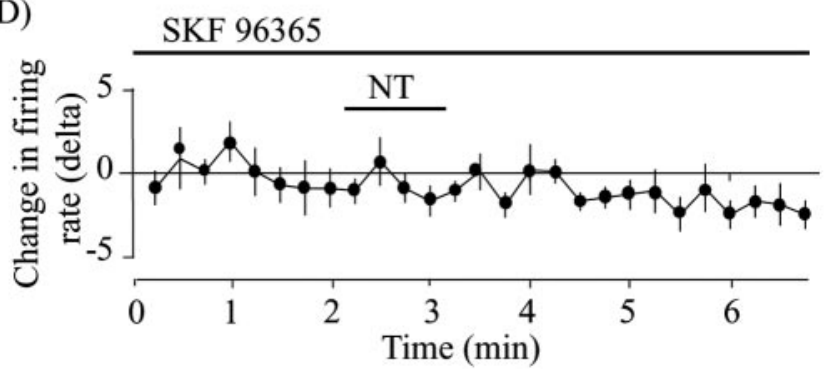

Figure 5. NT-evoked increase in firing rate requires $\mathrm{IP}_{3}$ receptors and cationic channels. $A$, Lack of effect of the PKC inhibitor bisindolylmaleimide on NT-evoked change in firing rate over time. Basal firing rate was, on average, $1.2 \pm 0.1 \mathrm{~Hz}$. $B$, Intra-pipette dialysis of the $\mathbb{P}_{3}$ receptor antagonist heparin blocked the ability of NT ( $100 \mathrm{~nm}$ ) to enhance firing rate. Basal firing rate was, on average, $0.75 \pm 0.05 \mathrm{~Hz}$. C, Extracellular $\mathrm{Zn}^{2+}(10 \mu \mathrm{M})$, a blocker of nonselective cationic channels, prevented NT(8-13)-evoked enhancement in firing rate in DAergic neurons. Basal firing rate was, on average, $0.7 \pm 0.1 \mathrm{~Hz}$. D, Extracellular SKF96365 $(1 \mu \mathrm{M})$, a different blocker of nonselective cationic channels, also prevented NT(8-13)-evoked enhancement in firing rate in DAergic neurons. Basal firing rate was, on average, $0.6 \pm 0.2 \mathrm{~Hz}$.

\section{Effects of NT on intracellular calcium in DAergic neurons}

DAergic neurons express NTS1 protein and mRNA (Nicot et al., 1995; Boudin et al., 1998). Considering the coupling of this receptor to PLC and $\mathrm{IP}_{3}$ production (Bozou et al., 1989; Tanaka et al., 1990; Hermans et al., 1992), the hypothesis that its activation causes intracellular $\mathrm{Ca}^{2+}$ elevation in DAergic neurons is reasonable but was untested. Calcium mobilization by NT has been demonstrated previously in other cell types (Sato et al., 1991; Hermans et al., 1995; Schaeffer et al., 1995; Borges et al., 1996; Trudeau, 2000). The present experiments provide the first detailed characterization of NT-evoked intracellular $\mathrm{Ca}^{2+}$ increase in DAergic neurons. We conclude that NT-evoked intracellular $\mathrm{Ca}^{2+}$ elevation mostly results from extracellular $\mathrm{Ca}^{2+}$ influx.
This may be considered surprising because of the predicted activation of $\mathrm{IP}_{3}$-dependent intracellular $\mathrm{Ca}^{2+}$ stores by NTS1 (Bozou et al., 1989; Tanaka et al., 1990; Hermans et al., 1992) (for review, see Vincent et al., 1999). However, NT-evoked intracellular $\mathrm{Ca}^{2+}$ elevation is blocked in $\mathrm{Ca}^{2+}$-free saline, and the $\mathrm{Ca}^{2+}$ ATPase blocker thapsigargin and the $\mathrm{IP}_{3}$ receptor antagonist heparin only delayed NT-evoked $\mathrm{Ca}^{2+}$ elevation. It should be noted that our observation that heparin prevents NT-evoked enhancement in firing rate in DAergic neurons demonstrates that activation of the $\mathrm{IP}_{3}$ pathway by NT is nonetheless critical for this excitatory effect of NT.

One possible mechanism explaining NT-activated $\mathrm{Ca}^{2+}$ entry in DAergic neurons is that NT-evoked increase in firing leads to the opening of voltage-dependent $\mathrm{Ca}^{2+}$ channels. However, this possibility can be ruled out because TTX did not prevent NTevoked elevation in $\left[\mathrm{Ca}^{2+}\right]_{\mathrm{i}}$. In addition, there was a clear temporal discordance between NT-evoked enhancement in firing and intracellular $\mathrm{Ca}^{2+}$ elevation. We can conclude that other $\mathrm{Ca}^{2+}$ influx pathways, such as nonselective cationic channels, are likely to be involved. This hypothesis is consistent with the evidence showing that, in VTA DAergic neurons, NT activates cationic channels (Jiang et al., 1994; Wu et al., 1995; Farkas et al., 1996). Such channels are likely to be $\mathrm{Ca}^{2+}$ permeable and could mediate NT-evoked $\mathrm{Ca}^{2+}$ influx. In addition, the partial involvement of channels activated by intracellular $\mathrm{Ca}^{2+}$ store depletion cannot presently be excluded. However, our finding that thapsigargin and heparin do not prevent NT-evoked $\mathrm{Ca}^{2+}$ elevation shows that most $\mathrm{Ca}^{2+}$ influx is not dependent on $\mathrm{Ca}^{2+}$ store depletion. This finding contrasts with our previous demonstration in mesencephalic astrocytes in which NT-evoked activation of thapsigargin-sensitive stores was absolutely required to trigger secondary $\mathrm{Ca}^{2+}$ influx (Trudeau, 2000).

\section{Mechanism mediating the excitatory effect of NT on DAergic neurons}

We showed that NT increases the firing rate of DAergic neurons. This result confirms previous studies. Indeed, when injected into the ventral mesencephalon, NT increases the firing rate of DAergic neurons (Werkman et al., 2000) and extracellular dopamine in terminal regions (Kalivas and Duffy, 1990; Laitinen et al., 1990; Sotty et al., 1998). In the current experiments, although the average effect of NT was an increase in cell firing, some response heterogeneity was noted. Of the 10 neurons tested, 2 showed no change in their firing frequency in response to NT, and 1 showed a decrease. The significance of such variability is unclear, but it could result from differential expression of NT receptors. This would fit with our observation that NT receptor antagonists did not completely block NT-evoked $\mathrm{Ca}^{2+}$ elevation in a few neurons. Previous work in brain slices also showed that SR 48692 only produces a partial attenuation of NT-induced excitation in DAergic neurons (Nalivaiko et al., 1998). Our results suggest that, although NTS1 may play the major role in NT-evoked excitation of DAergic neurons, some other NT receptor subtype that displays lower sensitivity to SR48692 or SR142948A could also be partly involved and perhaps cause opposite changes in excitability. It should be noted, however, that no clear demonstration is yet available for the ability of NTS2 to mediate $\mathrm{Ca}^{2+}$ elevation. In fact, it has been shown recently that NT does not cause $\mathrm{Ca}^{2+}$ elevation in cultured cerebellar neurons, cells that express high levels of NTS2 but no NTS1 (Sarret et al., 2002). However, a paradoxical $\mathrm{Ca}^{2+}$ mobilization by SR48692 has been demonstrated in these neurons, as well as in Chinese hamster ovary cells transfected with NTS2 (Yamada et al., 1998). Although NTS2 is 
not expressed at high levels in DAergic neurons (Mazella et al., 1996), evidence for its presence in astrocytes has been provided (Boudin et al., 1998). This leaves open the possibility that NT could also act indirectly on DAergic neurons through astrocytes (Trudeau, 2000). However, our finding that NT-evoked excitation of DAergic neurons can occur under conditions in which astrocytes are unresponsive to NT excludes an obligatory role of astrocytes. Our observation that NT-evoked excitation of DAergic neurons is enhanced under conditions in which astrocytes respond to NT leaves open the possibility that simultaneous activation of NT receptors on neurons and astrocytes is synergistic.

Our results suggest that the excitatory effect of NT on DAergic neurons is mediated by the PLC- $\mathrm{IP}_{3}$ pathway. Indeed, the blockade of NT-evoked firing by heparin demonstrates that activation of the $\mathrm{IP}_{3}$ receptor is a required step. This is in agreement with previous work showing that heparin or BAPTA blocks NTevoked cationic currents in acutely isolated DAergic neurons (Wu et al., 1995). The $\mathrm{Ca}^{2+}$ dependency of this excitatory effect and of cationic channel activation could result from the partial $\mathrm{Ca}^{2+}$ dependency of PLC (Billah et al., 1980; Lund et al., 2000). Calcium could also be required because of the involvement of $\mathrm{Ca}^{2+}$-activated nonselective cationic conductances. Previous experiments have revealed that NT increases the firing rate of DAergic neurons by activating nonselective cationic conductances (Seutin et al., 1989; Mercuri et al., 1993; Farkas et al., 1996). In addition to NT receptors, it is known that other $\mathrm{G}_{\mathrm{q}}$-coupled receptors can enhance $\mathrm{Ca}^{2+}$-activated nonselective cationic conductances through an $\mathrm{IP}_{3}$ - and $\mathrm{Ca}^{2+}$-dependent signaling pathway (Wu and Wang, 1996; Congar et al., 1997; Lee et al., 1999).

Within the context of the possible involvement of $\mathrm{Ca}^{2+}$. activated nonselective cationic conductances, it should be noted that there is partial temporal discordance between the NTevoked increase in firing rate and calcium elevation (compare Fig. $1 C$ with Fig. $2 A$ ). Together with our finding that BAPTA blocks NT-evoked firing, this observation demonstrates that $\mathrm{Ca}^{2+}$ elevation is necessary but not sufficient to promote firing. This argues against a simple mechanism whereby NT leads directly to activation of $\mathrm{Ca}^{2+}$-activated cationic channels. If this were the case, one would expect firing rate increases to closely follow intracellular $\mathrm{Ca}^{2+}$ elevation. Our results suggest that $\mathrm{Ca}^{2+}$ does not act directly to cause an increase in excitability. Rather, our findings favor a more indirect hypothesis implicating, for example, the sequential activation of receptor-operated $\mathrm{Ca}^{2+}$ channels, followed by some $\mathrm{Ca}^{2+}$-activated pathway leading to delayed enhancements in membrane excitability. Considering that NT can also inhibit potassium channels (Kirkpatrick and Bourque, 1995; Farkas et al., 1997), delayed inhibition of such channels appears like a possible mechanism.

The molecular identity of the receptor-operated cationic channels activated by NT in DAergic neurons remains to be established. A candidate family of channels is TRP nonselective cationic channels, first identified in Drosophila (Hardie and Minke, 1992) but recently showed to be widely expressed in mammalian neurons (Wes et al., 1995; Zhu et al., 1996; Boulay et al., 1997; Philipp et al., 1998). Such channels are highly permeable to $\mathrm{Ca}^{2+}$ and are activated through $\mathrm{G}_{\mathrm{q}}$-coupled receptors. Interestingly, it has been reported that TRP channels can be activated through the $\mathrm{IP}_{3}$ receptor (Boulay et al., 1999; Ma et al., 2000). The expression of TRP channels in DAergic neurons has not yet been closely examined, but preliminary immunocytochemical experiments have allowed us to determine that a number of TRP channels are present in cultured DAergic neurons (G. Fortin, F. J. Michel, F. St. Gelais, and L.-E. Trudeau, unpublished results).
Our finding that $\mathrm{Zn}^{2+}$ and SKF96365 block NT-evoked enhancement in firing in DAergic neurons is compatible with the involvement of TRP-like channels because these agents have been known previously to block nonselective cationic conductances (Merritt et al., 1990; Denning et al., 1994; Guse et al., 1997). Zinc has been shown recently to block channels formed by TRP6 in neurons (Kaneko et al., 2002).

In summary, our findings provide a better understanding of the mechanism mediating the well known excitatory effect of NT on DAergic neurons. Future experiments will have to be directed toward explaining the delayed nature of NT-evoked firing rate increase. In addition, an investigation of the possible activation of TRP-like channels by NT may lead to a more complete understanding of the NT-evoked $\mathrm{Ca}^{2+}$-influx pathway.

\section{References}

Araque A, Sanzgiri RP, Parpura V, Haydon PG (1998) Calcium elevation in astrocytes causes an NMDA receptor-dependent increase in the frequency of miniature synaptic currents in cultured hippocampal neurons. J Neurosci 18:6822-6829.

Billah MM, Lapetina EG, Cuatrecasas P (1980) Phospholipase A2 and phospholipase $\mathrm{C}$ activities of platelets. Differential substrate specificity, $\mathrm{Ca}^{2+}$ requirement, $\mathrm{pH}$ dependence, and cellular localization. J Biol Chem 255:10227-10231.

Borges S, Gleason E, Frerking M, Wilson M (1996) Neurotensin induces calcium oscillations in cultured amacrine cells. Vis Neurosci 13:311-318.

Boudin H, Pelaprat D, Rostene W, Pickel VM, Beaudet A (1998) Correlative ultrastructural distribution of neurotensin receptor proteins and binding sites in the rat substantia nigra. J Neurosci 18:8473-8484.

Boulay G, Zhu X, Peyton M, Jiang M, Hurst R, Stefani E, Birnbaumer L (1997) Cloning and expression of a novel mammalian homolog of Drosophila transient receptor potential (Trp) involved in calcium entry secondary to activation of receptors coupled by the Gq class of $\mathrm{G}$ protein. J Biol Chem 272:29672-29680.

Boulay G, Brown DM, Qin N, Jiang M, Dietrich A, Zhu MX, Chen Z, Birnbaumer M, Mikoshiba K, Birnbaumer L (1999) Modulation of $\mathrm{Ca}^{2+}$ entry by polypeptides of the inositol 1,4,5- trisphosphate receptor (IP3R) that bind transient receptor potential (TRP): evidence for roles of TRP and IP3R in store depletion-activated $\mathrm{Ca}^{2+}$ entry. Proc Natl Acad Sci USA 96:14955-14960.

Bourque MJ, Trudeau LE (2000) GDNF enhances the synaptic efficacy of dopaminergic neurons in culture. Eur J Neurosci 12:3172-3180.

Bozou JC, Rochet N, Magnaldo I, Vincent JP, Kitabgi P (1989) Neurotensin stimulates inositol trisphosphate-mediated calcium mobilization but not protein kinase C activation in HT29 cells. Involvement of a G-protein. Biochem J 264:871-878.

Cador M, Rivet JM, Kelley AE, Le Moal M, Stinus L (1989) Substance P, neurotensin and enkephalin injections into the ventral tegmental area: comparative study on dopamine turnover in several forebrain structures. Brain Res 486:357-363.

Cardozo DL (1993) Midbrain dopaminergic neurons from postnatal rat in long-term primary culture. Neuroscience 56:409-421.

Chabry J, Labbe-Jullie C, Gully D, Kitabgi P, Vincent JP, Mazella J (1994) Stable expression of the cloned rat brain neurotensin receptor into fibroblasts: binding properties, photoaffinity labeling, transduction mechanisms, and internalization. J Neurochem 63:19-27.

Congar P, Leinekugel X, Ben-Ari Y, Crepel V (1997) A long-lasting calciumactivated nonselective cationic current is generated by synaptic stimulation or exogenous activation of group I metabotropic glutamate receptors in CA1 pyramidal neurons. J Neurosci 17:5366-5379.

Congar P, Bergevin A, Trudeau LE (2002) D2 receptors inhibit the secretory process downstream from calcium influx in dopaminergic neurons: implication of $\mathrm{K}^{+}$channels. J Neurophysiol 87:1046-1056.

Dana C, Pelaprat D, Vial M, Brouard A, Lhiaubet AM, Rostene W (1991) Characterization of neurotensin binding sites on rat mesencephalic cells in primary culture. Brain Res Dev Brain Res 61:259-264.

Denning GM, Clark RA, Welsh MJ (1994) cAMP and inositol 1,4,5trisphosphate increase $\mathrm{Ca}^{2+}$ in $\mathrm{HT}-29$ cells by activating different $\mathrm{Ca}^{2+}$ influx pathways. Am J Physiol 267:C776-C783.

Faggin BM, Zubieta JK, Rezvani AH, Cubeddu LX (1990) Neurotensin- 
induced dopamine release in vivo and in vitro from substantia nigra and nucleus caudate. J Pharmacol Exp Ther 252:817-825.

Farkas RH, Chien PY, Nakajima S, Nakajima Y (1996) Properties of a slow nonselective cation conductance modulated by neurotensin and other neurotransmitters in midbrain dopaminergic neurons. J Neurophysiol 76:1968-1981.

Farkas RH, Chien PY, Nakajima S, Nakajima Y (1997) Neurotensin and dopamine $\mathrm{D} 2$ activation oppositely regulate the same $\mathrm{K}^{+}$conductance in rat midbrain dopaminergic neurons. Neurosci Lett 231:21-24.

Govoni S, Hong JS, Yang HY, Costa E (1980) Increase of neurotensin content elicited by neuroleptics in nucleus accumbens. J Pharmacol Exp Ther 215:413-417.

Grace AA, Onn SP (1989) Morphology and electrophysiological properties of immunocytochemically identified rat dopamine neurons recorded in vitro. J Neurosci 9:3463-3481.

Grisshammer R, Hermans E (2001) Functional coupling with Galpha(q) and Galpha(i1) protein subunits promotes high-affinity agonist binding to the neurotensin receptor NTS- 1 expressed in Escherichia coli. FEBS Lett 493:101-105.

Guse AH, de Wit C, Klokow T, Schweitzer K, Mayr GW (1997) Unique properties of the capacitative $\mathrm{Ca}^{2+}$-entry antagonist LU 52396: its inhibitory activity depends on the activation state of the cells. Cell Calcium 22:91-97.

Hardie RC, Minke B (1992) The trp gene is essential for a light-activated $\mathrm{Ca}^{2+}$ channel in Drosophila photoreceptors. Neuron 8:643-651.

Hausser M, Stuart G, Racca C, Sakmann B (1995) Axonal initiation and active dendritic propagation of action potentials in substantia nigra neurons. Neuron 15:637-647.

Heaulme M, Leyris R, Le Fur G, Soubrie P (1997) Involvement of potentially distinct neurotensin receptors in neurotensin-induced stimulation of striatal. Neuropharmacology 36:1447-1454.

Hermans E, Maloteaux JM, Octave JN (1992) Phospholipase Cactivation by neurotensin and neuromedin $\mathrm{N}$ in Chinese hamster ovary cells expressing the rat neurotensin receptor. Brain Res Mol Brain Res 15:332-338.

Hermans E, Gailly P, Gillis JM, Octave JN, Maloteaux JM (1995) Lack of rapid desensitization of $\mathrm{Ca}^{2+}$ responses in transfected CHO cells expressing the rat neurotensin receptor despite agonist-induced internalization. J Neurochem 64:2518-2525.

Hetier E, Boireau A, Dubedat P, Blanchard JC (1988) Neurotensin effects on evoked release of dopamine in slices from striatum, nucleus accumbens and prefrontal cortex in rat. Naunyn Schmiedebergs Arch Pharmacol 337:13-17.

Jiang ZG, Pessia M, North RA (1994) Neurotensin excitation of rat ventral tegmental neurones. J Physiol (Lond) 474:119-129.

Kalivas PW, Duffy P (1990) Effect of acute and daily neurotensin and enkephalin treatments on extracellular dopamine in the nucleus accumbens. J Neurosci 10:2940-2949.

Kalivas PW, Burgess SK, Nemeroff CB, Prange AJ Jr (1983) Behavioral and neurochemical effects of neurotensin microinjection into the ventral tegmental area of the rat. Neuroscience 8:495-505.

Kaneko S, Higuchi S, Kawakami S, Kume T, Akaike A, Satoh M, Mori Y (2002) Expression and function of TRP channels in cultured cerebral cortical neurons from fetal rat. Soc Neurosci Abstr 28:341.9.

Kinkead B, Shahid S, Owens MJ, Nemeroff CB (2000) Effects of acute and subchronic administration of typical and atypical antipsychotic drugs on the neurotensin system of the rat brain. J Pharmacol Exp Ther 295:67-73.

Kirkpatrick K, Bourque CW (1995) Effects of neurotensin on rat supraoptic nucleus neurones in vitro. J Physiol (Lond) 482:373-381.

Kiselyov K, Mignery GA, Zhu MX, Muallem S (1999) The N-terminal domain of the IP3 receptor gates store-operated hTrp3 channels. Mol Cell $4: 423-429$.

Laitinen K, Crawley JN, Mefford IN, De Witte P (1990) Neurotensin and cholecystokinin microinjected into the ventral tegmental area modulate microdialysate concentrations of dopamine and metabolites in the posterior nucleus accumbens. Brain Res 523:342-346.

Lee K, Dixon AK, Gonzalez I, Stevens EB, McNulty S, Oles R, Richardson PJ, Pinnock RD, Singh L (1999) Bombesin-like peptides depolarize rat hippocampal interneurones through interaction with subtype 2 bombesin receptors. J Physiol (Lond) 518:791-802.

Legault M, Congar P, Michel FJ, Trudeau LE (2002) Presynaptic action of neurotensin on cultured ventral tegmental area dopaminergic neurones. Neuroscience 111:177-187.
Li AH, Hwang HM, Tan PP, Wu T, Wang HL (2001a) Neurotensin excites periaqueductal gray neurons projecting to the rostral ventromedial medulla. J Neurophysiol 85:1479-1488.

Li AH, Yeh TH, Tan PP, Hwang HM, Wang HL (2001b) Neurotensin excitation of serotonergic neurons in the rat nucleus raphe magnus: ionic and molecular mechanisms. Neuropharmacology 40:1073-1083.

Lund PE, Shariatmadari R, Uustare A, Detheux M, Parmentier M, Kukkonen JP, Akerman KE (2000) The orexin OX1 receptor activates a novel $\mathrm{Ca}^{2+}$ influx pathway necessary for coupling to phospholipase C. J Biol Chem 275:30806-30812.

Ma HT, Patterson RL, van Rossum DB, Birnbaumer L, Mikoshiba K, Gill DL (2000) Requirement of the inositol trisphosphate receptor for activation of store-operated $\mathrm{Ca}^{2+}$ channels. Science 287:1647-1651.

Martin S, Botto JM, Vincent JP, Mazella J (1999) Pivotal role of an aspartate residue in sodium sensitivity and coupling to $G$ proteins of neurotensin receptors. Mol Pharmacol 55:210-215.

Mazella J, Botto JM, Guillemare E, Coppola T, Sarret P, Vincent JP (1996) Structure, functional expression, and cerebral localization of the levocabastine-sensitive neurotensin/neuromedin $\mathrm{N}$ receptor from mouse brain. J Neurosci 16:5613-5620.

Mercuri NB, Stratta F, Calabresi P, Bernardi G (1993) Neurotensin induces an inward current in rat mesencephalic dopaminergic neurons. Neurosci Lett 153:192-196.

Merritt JE, Armstrong WP, Benham CD, Hallam TJ, Jacob R, Jaxa-Chamiec A, Leigh BK, McCarthy SA, Moores KE, Rink TJ (1990) SK\&F 96365, a novel inhibitor of receptor-mediated calcium entry. Biochem J 271:515-522.

Michel FJ, Trudeau LE (2000) Clozapine inhibits synaptic transmission at GABAergic synapses established by ventral tegmental area neurones in culture. Neuropharmacology 39:1536-1543.

Nalivaiko E, Michaud JC, Soubrie P, Le Fur G (1998) Electrophysiological evidence for putative subtypes of neurotensin receptors in guinea-pig mesencephalic dopaminergic neurons. Neuroscience 86:799-811.

Nicot A, Rostene W, Berod A (1995) Differential expression of neurotensin receptor $\mathrm{mRNA}$ in the dopaminergic cell groups of the rat diencephalon and mesencephalon. J Neurosci Res 40:667-674.

Nouel D, Sarret P, Vincent JP, Mazella J, Beaudet A (1999) Pharmacologi$\mathrm{cal}$, molecular and functional characterization of glial neurotensin receptors. Neuroscience 94:1189-1197.

Palacios JM, Kuhar MJ (1981) Neurotensin receptors are located on dopamine-containing neurones in rat midbrain. Nature 294:587-589.

Philipp S, Hambrecht J, Braslavski L, Schroth G, Freichel M, Murakami M, Cavalie A, Flockerzi V (1998) A novel capacitative calcium entry channel expressed in excitable cells. EMBO J 17:4274-4282.

Pinnock RD (1985) Neurotensin depolarizes substantia nigra dopamine neurones. Brain Res 338:151-154.

Rompre PP, Bauco P, Gratton A (1992) Facilitation of brain stimulation reward by mesencephalic injections of neurotensin-(1-13). Eur J Pharmacol 211:295-303.

Sarret P, Gendron L, Kilian P, Nguyen HM, Gallo-Payet N, Payet MD, Beaudet A (2002) Pharmacology and functional properties of NTS2 neurotensin receptors in cerebellar granule cells. J Biol Chem 277:36233-36243.

Sato M, Shiosaka S, Tohyama M (1991) Neurotensin and neuromedin N elevate the cytosolic calcium concentration via transiently appearing neurotensin binding sites in cultured rat cortex cells. Brain Res Dev Brain Res 58:97-103.

Schaeffer P, Laplace MC, Savi P, Pflieger AM, Gully D, Herbert JM (1995) Human umbilical vein endothelial cells express high affinity neurotensin receptors coupled to intracellular calcium release. J Biol Chem 270:3409-3413.

Seutin V, Massotte L, Dresse A (1989) Electrophysiological effects of neurotensin on dopaminergic neurones of the ventral tegmental area of the rat in vitro. Neuropharmacology 28:949-954.

Sotty F, Souliere F, Brun P, Chouvet G, Steinberg R, Soubrie P, Renaud B, Suaud-Chagny MF (1998) Differential effects of neurotensin on dopamine release in the caudal and rostral nucleus accumbens: a combined in vivo electrochemical and electrophysiological study. Neuroscience 85:1173-1182.

Stowe ZN, Nemeroff CB (1991) The electrophysiological actions of neurotensin in the central nervous system. Life Sci 49:987-1002.

Sulzer D, Joyce MP, Lin L, Geldwert D, Haber SN, Hattori T, Rayport S 
(1998) Dopamine neurons make glutamatergic synapses in vitro. J Neurosci 18:4588-4602.

Szigethy E, Beaudet A (1989) Correspondence between high affinity 125Ineurotensin binding sites and dopaminergic neurons in the rat substantia nigra and ventral tegmental area: a combined radioautographic and immunohistochemical light microscopic study. J Comp Neurol 279:128-137.

Tanaka K, Masu M, Nakanishi S (1990) Structure and functional expression of the cloned rat neurotensin receptor. Neuron 4:847-854.

Trudeau LE (2000) Neurotensin regulates intracellular calcium in ventral tegmental area astrocytes: evidence for the involvement of multiple receptors. Neuroscience 97:293-302.

Vincent JP, Mazella J, Kitabgi P (1999) Neurotensin and neurotensin receptors. Trends Pharmacol Sci 20:302-309.

Wang HL, Wu T (1996) G alpha q/11 mediates neurotensin excitation of substantia nigra dopaminergic neurons. Brain Res Mol Brain Res 36:29-36.

Werkman TR, Kruse CG, Nievelstein H, Long SK, Wadman WJ (2000) Neurotensin attenuates the quinpirole-induced inhibition of the firing rate of dopamine neurons in the rat substantia nigra pars compacta and the ventral tegmental area. Neuroscience 95:417-423.
Wes PD, Chevesich J, Jeromin A, Rosenberg C, Stetten G, Montell C (1995) TRPC1, a human homolog of a Drosophila store-operated channel. Proc Natl Acad Sci USA 92:9652-9656.

Wu T, Wang HL (1996) The excitatory effect of cholecystokinin on rat neostriatal neurons: ionic and molecular mechanisms. Eur J Pharmacol 307:125-132.

Wu T, Li A, Wang HL (1995) Neurotensin increases the cationic conductance of rat substantia nigra dopaminergic neurons through the inositol 1,4,5-trisphosphate-calcium pathway. Brain Res 683:242-250.

Yamada M, Yamada M, Watson MA, Richelson E (1994) Deletion mutation in the putative third intracellular loop of the rat neurotensin receptor abolishes polyphosphoinositide hydrolysis but not cyclic AMP formation in CHO-K1 cells. Mol Pharmacol 46:470-476.

Yamada M, Yamada M, Lombet A, Forgez P, Rostene W (1998) Distinct functional characteristics of levocabastine sensitive rat neurotensin NT2 receptor expressed in Chinese hamster ovary cells. Life Sci 62:PL375—PL380.

Zhu X, Jiang M, Peyton M, Boulay G, Hurst R, Stefani E, Birnbaumer L (1996) trp, a novel mammalian gene family essential for agonistactivated capacitative $\mathrm{Ca}^{2+}$ entry. Cell 85:661-671. 